\title{
TRANSPORT OF PROTEINS AND SULFATED MUCOPOLYSACCHARIDES IN THE GOLDFISH VISUAL SYSTEM $* \dagger$
}

\author{
JOHN S. ELAM $\ddagger$ and BERNARD W. AGRANOFF \\ Mental Health Research Institute University of Michigan \\ Ann Arbor, Michigan 48104
}

\section{SUMMARY}

${ }^{3} \mathrm{H}$-Proline, ${ }^{3} \mathrm{H}$-asparagine and $\mathrm{Na}_{2}{ }^{35} \mathrm{SO}_{4}$ have been found to be highly specific markers for axonal transport in the goldfish visual system. The amino acids label both rapidly and slowly transported proteins while the ${ }^{35} \mathrm{~S}$ is recovered mainly with the rapidly transported materials, including protein-bound mucopolysaccharides. These precursors have been used to study the rate of transport, the subcellular distribution and the rate of turnover of transported proteins in the nerve terminals.

\section{INTRODUCTION}

Numerous studies have now demonstrated the rapid and slow axonal transport of protein in a variety of neurons (for reviews, see Grafstein, 1969 and Weiss, 1969). In general, these studies have concentrated on either the movement of material through a specific region of a nerve tract, or on the arrival and accumulation of such materials in nerve terminals. For studies of the latter type, the visual systems of fish (Grafstein, 1967; McEwen and Grafstein, 1968; Elam and Agranoff, 1971; Forman et al., 1971) and birds (Marchisio and Sjöstrand, 1971; Carton and Appel, 1971; Bondy and Morelos, 1971; Cuénod and Schonback, 1971) have offered several intrinsic advantages. Their eyes provide a well-defined space for the facile and reproducible introduction of isotopic precursors; the retinal ganglion fibers completely cross to the contralateral optic tectum of the brain, allowing the ipsilateral tectum to be used as a control for background isotope incorporation; in addition, the optic tectum is readily dissected, providing a quantitative yield of optic nerve terminals

* This paper was presented at a symposium on axoplasmic flow at the second meeting of the American Society for Neurochemistry, Hershey, Pennsylvania, March 15, 1971.

† This work was supported by grant MH 12506 of the National Institute of Mental Health and GB-5125X of the National Science Foundation.

$\ddagger$ Interdisciplinary fellow, supported by Training Grant $\mathrm{MH} 07417$ from the National Institute of Mental Health. 


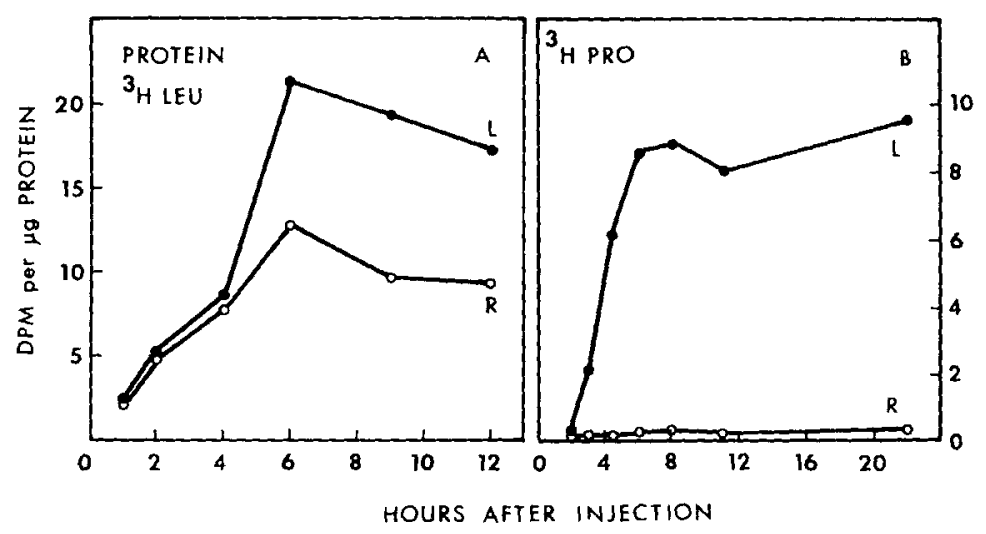

Fig. 1. Specific activity of the protein of the left $(\mathbf{L})$ and right $(\mathbf{R})$ optic tecta after intraocular injection of (A) ${ }^{3} \mathrm{H}$-leucine $(15 \mu \mathrm{Ci}, 1.1$ nmole $)$ or (B) ${ }^{3} \mathrm{H}$-proline $(2.5 \mu \mathrm{Ci}$, $0.3 \mathrm{nmole})$. Groups of 3-5 fish were pooled for each time point. Protein was isolated as described previously (Elam and Agranoff, 1971).

for autoradiographic or biochemical analysis. In the present paper we review our work on axonal transport in the goldfish optic system.

Isotopic markers for rapidly transported proteins. Tritiated amino acids. Initial studies utilizing the intraocular injection of ${ }^{3} \mathrm{H}$ leucine in the goldfish (Grafstein, 1967; McEwen and Grafstein, 1968) indicated rapid and slow axonal transport of protein in the optic nerve at the rates of 40 and $0.4 \mathrm{~mm}$ per day, respectively. Similar experiments demonstrating the more rapid transport have been reported from our laboratory [Fig. 1(A)] (Elam and Agranoff, 1971). In this and the previous studies, the greater specific activity of the left (contralateral) tectum was shown to be due to the accumulation of axonally transported radioactive proteins and not to transport of free leucine and local incorporation in the tectum. The large amount of labeling on the right side is due to ${ }^{3} \mathrm{H}$-leucine brought to the brain by the blood and is distributed symmetrically. Measurement of transported radioactivity thus requires the subtraction of right specific activity from the left, a correction which is seen to be very large in the ${ }^{3} \mathrm{H}$-leucine experiments [Fig. 1(A)]. We have found that intraocular injection of other tritiated amino acids, notably proline or asparagine, produces more efficient labeling of the transported protein and in addition, relatively little incorporation in the brain as a whole [Fig. 1(B)] (Elam and Agranoff, 1971). Use of these amino acids now generally allows the study of axonal transport in this system without correction for background labeling. The metabolic basis of the difference between leucine and proline in this regard is not completely understood. Following injection of equimolar amounts of the same specific activity, about twice as much radioactivity from proline as from leucine is incorporated into retinal protein while only $1 / 5$ as much free ${ }^{3} \mathrm{H}$-proline as ${ }^{3} \mathrm{H}$-leucine reaches the brain systemically. 
Table 1

Distribution of Radioactivity 8 Hours after Injection of ${ }^{3} \mathrm{H}$-Proline $(2 \mu \mathrm{Ci}, 0.3$ nmoles $)$ into the Right Eye

\begin{tabular}{lc} 
& Injected \\
Right retina protein & 14.6 \\
Whole right lens & 9.5 \\
Left tectum protein & 0.14 \\
Right tectum protein & 0.006 \\
\hline
\end{tabular}

As can be seen in Table 1, the rapidly transported radioactivity represents approximately $1 \%$ of the radioactivity incorporated into retinal protein.

$\mathrm{Na}_{2}{ }^{35} \mathrm{SO}_{4}$. Recently we have reported the rapid axonal transport of ${ }^{35}$ S-labeled sulfated glycoproteins and sulfated mucopolysaccharides in the goldfish optic system (Elam et al., 1970). It was found that intraocular injection of carrier-free $\mathrm{Na}_{2}{ }^{35} \mathrm{SO}_{4}$ leads to an accumulation of protein-bound radioactivity in the contralateral tectum at a rate which is very similar to that observed with ${ }^{3} \mathrm{H}$-proline [Fig. 2(B) ]. As found with the tritiated amino acids, the left-right difference in labeling is apparently

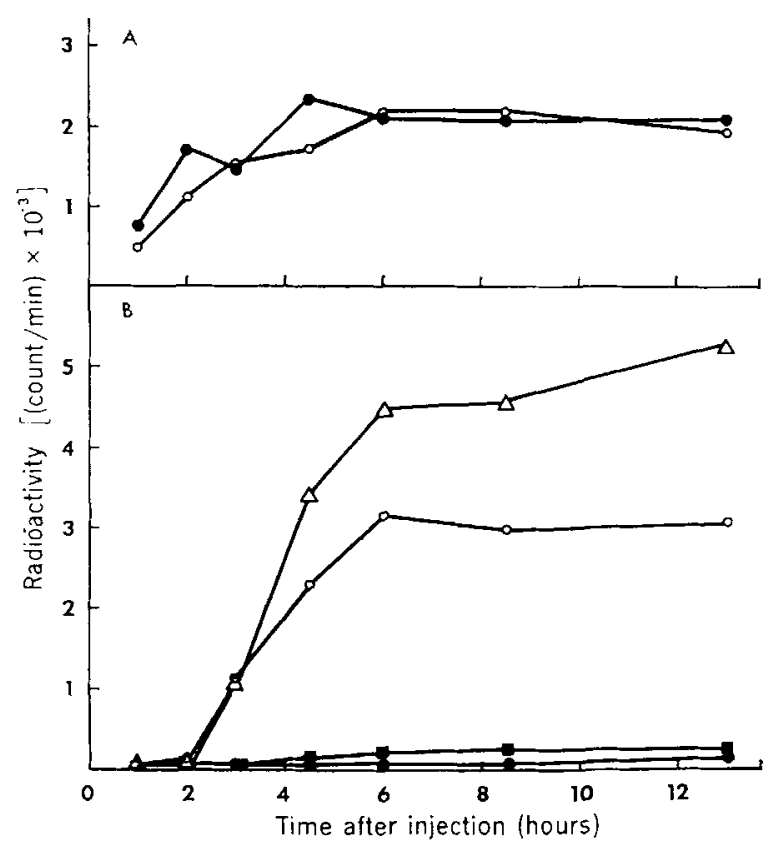

Fig. 2. Appearance of radioactivity in left and right tectal fractions following injection of ${ }^{3} \mathrm{H}$-proline and $\mathrm{Na}_{2}{ }^{35} \mathrm{SO}_{4}$ into the right eye. (A) Combined chlorolormmethanol and methanol-water washes. Open circles, ${ }^{35} \mathrm{~S}$ in left tectum; and closed circles, ${ }^{35} \mathrm{~S}$ in right tectum. (B) Supernatant after protease digestion of residue. Open triangles, ${ }^{3} \mathrm{H}$ in the left tectum; closed squares, ${ }^{3} \mathrm{H}$ in the right tectum; open circles, ${ }^{3} \mathrm{~S}$ in the left tectum; and closed circles, ${ }^{35} \mathrm{~S}$ in the right tectum (from Elam et al., 1970). 
not due to the transport of low molecular weight precursors, since chloroform:methanol and methanol:water washes show negligible left-right asymmetry of labeling at early times [Fig. 2(A)].

When the chloroform:methanol-methanol: water residue was digested with protease, about half of the labeled material was precipitable in cetylpyridinium bromide and ethanol and soluble in $10 \%$ trichloroacetic acid, properties characteristic of sulfated mucopolysaccharides. This fraction had a hexosamine-to-uronic acid ratio of $1: 1$ and on cellulose acetate electrophoresis, yielded 3 bands. The fastest band comigrated with standard chondroitin sulfate and contained $30 \%$ of the radioactivity. This middle band migrated slightly slower than standard heparan sulfate and contained the remainder of the radioactivity. The slowest band was unlabeled and comigrated with hyaluronic acid. Additional studies on susceptibility to hyaluronidase and determination of $\mathrm{N}$-sulfate content have further indicated that chondroitin sulfate and heparan sulfate are the labeled mucopolysaccharides (Elam et al., 1970).

The portion of the protease digest radioactivity which was not precipitable in cetylpyridinium bromide has been shown to be $70 \%$ nondialyzable. When the dialysate is placed on a Sephadex G-50 column, it is eluted with $0.1 \mathrm{~N} \mathrm{NaCl}$ as a broad peak suggestive of a polydisperse population with molecular weights ranging from 10,000 to 500 (Fig. 3). The properties of this fraction are similar to those of a sulfated glycopep-

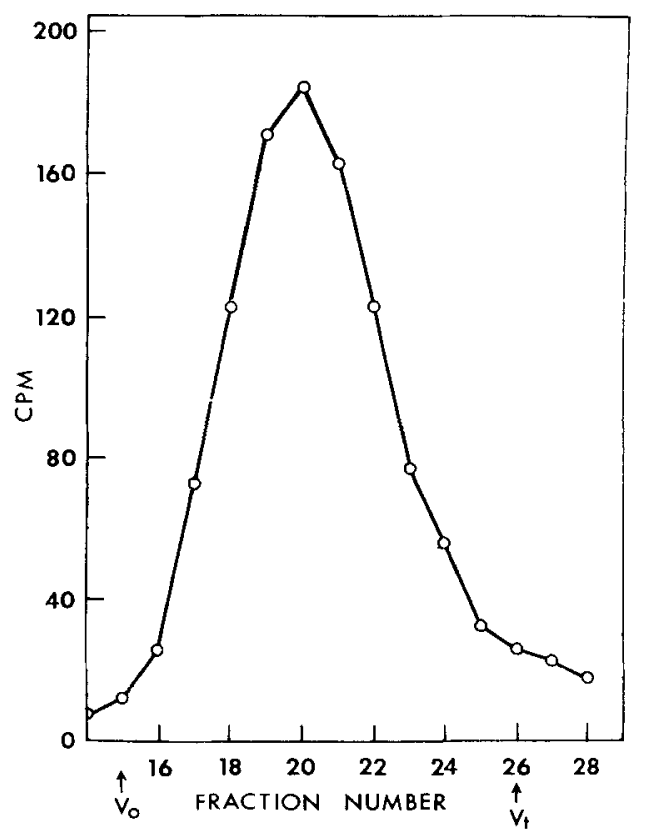

Fig. 3. Elution of dialysed cetylpyridinium bromide non-precipitable fraction from a column $(1.27 \times 18.5 \mathrm{~cm})$ of Sephadex G50. Equilibration and elution was in 0.1 $\mathrm{N} \mathrm{NaCl}$. 
Table 2

Effect of Intraocular Acetoxycycloheximide (AXM) on Tectal Labeling

\begin{tabular}{ccccc}
\hline $\begin{array}{c}\text { Time (min) } \\
\text { between AXM } \\
(50 \text { ng) and } \\
\text { isotope } \\
\text { injection }\end{array}$ & $\begin{array}{c}\text { 'H } \\
(\mathbf{L}-\mathbf{R}) \mathbf{c p m}\end{array}$ & $\begin{array}{c}\text { Inhibition } \\
(\%)\end{array}$ & $\begin{array}{c}{ }^{35} \mathbf{S} \\
(\mathbf{L}-\mathbf{R}) \mathbf{c p m}\end{array}$ & $\begin{array}{c}\text { Inhibition } \\
(\%)\end{array}$ \\
\hline Control & 4660 & - & 2930 & - \\
0 & 68 & 99 & 790 & 73 \\
30 & 0 & 100 & 305 & 90 \\
60 & 150 & 97 & 130 & 96 \\
\hline
\end{tabular}

tide fraction recently isolated from rat brain (Margolis and Margolis, 1970).

Since the sulfated macromolecules appear to be transported bound to the rapidly transported proteins, it was of interest to determine whether sulfate labeling is inhibited by intraocular injection of acetoxycycloheximide (AXM) in amounts which have been shown to quantitatively inhibit incorporation of amino acids into rapidly transported protein (McEwen and Grafstein, 1968). As seen in Table 2, simultaneous injection of $\mathrm{AXM},{ }^{3} \mathrm{H}$-proline and ${ }^{35} \mathrm{SO}_{4}$ brings about a $95 \%$ inhibition of amino acid labeling of rapidly transported protein and a $73 \%$ inhibition

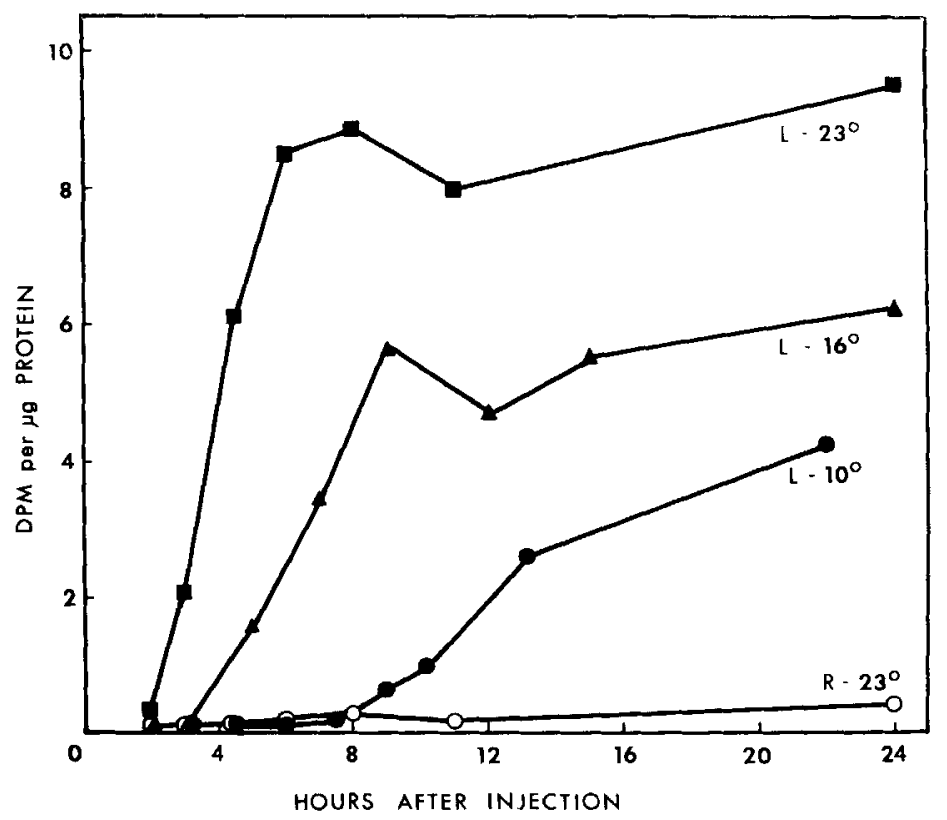

Fig. 4. Labeling of protein in the optic tectum of fish stored at various temperatures. Fish were stored at the stated temperatures for 2 days prior to ocular injection of ${ }^{3} \mathrm{H}$ proline $(2.5 \mu \mathrm{Ci}, 0.31 \mathrm{nmole})$. Groups of four fish were pooled for each point. (L) left tectum; (R) right tectum (from Elam and Agranoff, 1971). 


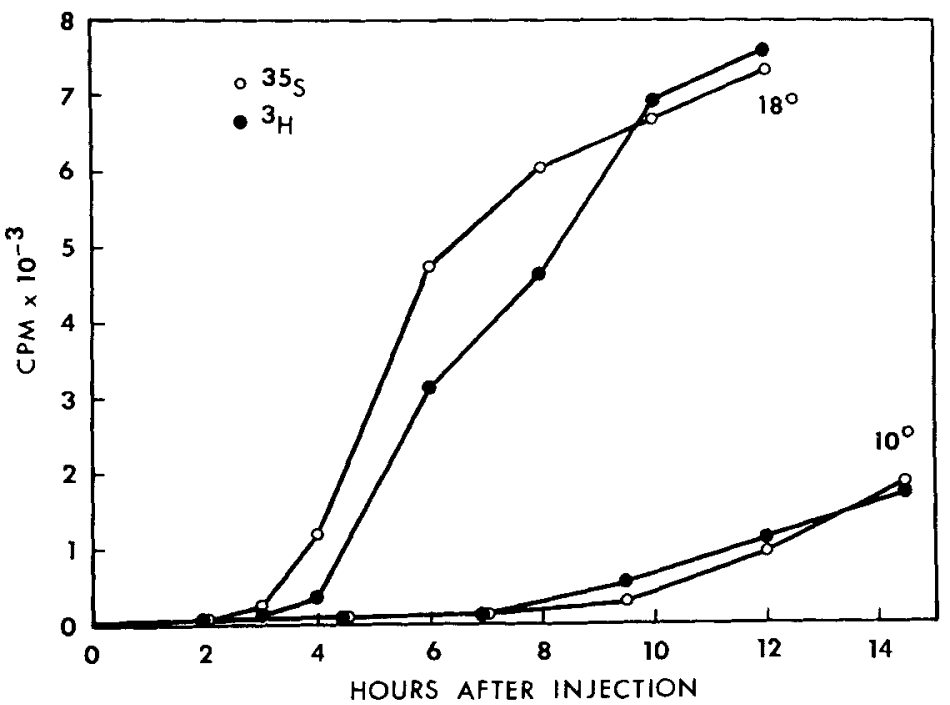

Fig. 5. Labeling of the optic tectum following intraocular injection of $\mathrm{Na}_{2}{ }^{3 \mathrm{SO}_{4}}$ $(12 \mu \mathrm{Ci})$ and ${ }^{3} \mathrm{H}$-proline $(1 \mu \mathrm{Ci})$ at $18^{\circ} \mathrm{C}$ and $10^{\circ} \mathrm{C} .{ }^{3} \mathrm{H}$ radioactivity was measured in protein, ${ }^{35} \mathrm{~S}$ radoiactivity was measured in chloroform: $\mathrm{MeOH}-\mathrm{MeOH}-\mathrm{H}_{2} \mathrm{O}$ residue. Fish were stored at each temperature for 2 days prior to injection. Five were pooled for each time point.

of ${ }^{35} \mathrm{~S}$ labeling. There thus appears to be incomplete coupling between protein synthesis and ${ }^{35} \mathrm{SO}_{4}$ incorporation, perhaps reflecting a small pool of preformed glycoproteins which can act as sulfate acceptors. When AXM is administered 30 min ahead of the isotopes there is quantitative

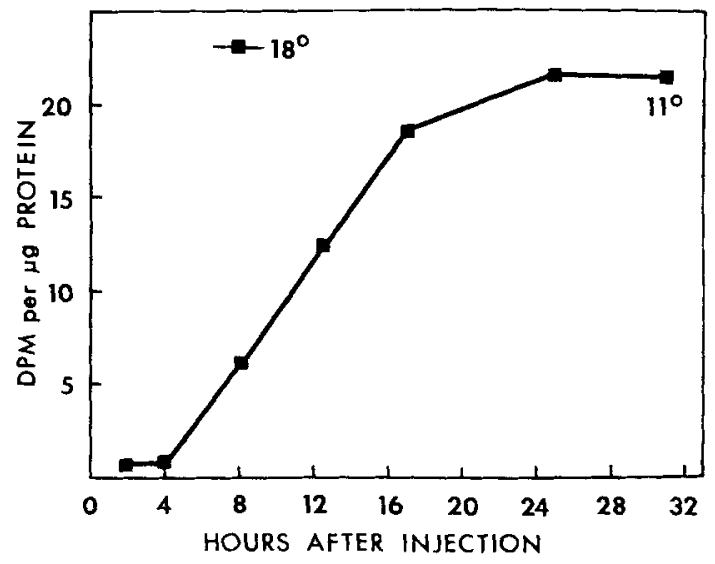

Fig. 6. Labeling of protein in the optic tectum in fish stored at $18^{\circ} \mathrm{C}$ for $1.75 \mathrm{hr}$ after injection and $11^{\circ} \mathrm{C}$ for the remainder of the experiment. Injection was with 5 ${ }_{\mu} \mathrm{Ci}\left(0.9\right.$ nmoles) ${ }^{8} \mathrm{H}$-proline. Groups of 4 fish were pooled for each time point. The specific activity of control fish left at $18^{\circ}$ for $8 \mathrm{hr}$ is also shown. 
inhibition of incorporation of both ${ }^{3} \mathrm{H}$ and ${ }^{35} \mathrm{~S}$ into transported proteins (Table 2).

Transport rates. We have utilized ${ }^{3} \mathrm{H}$-proline to examine the rate of rapid axonal transport at various temperatures (Fig. 4) (Elam and Agranoff, 1971). Additional experiments utilizing a double label demonstrate that ${ }^{3} \mathrm{H}$-proline and ${ }^{35} \mathrm{SO}_{4}$ labeled components are similarly affected by temperature (Fig. 5). At $23^{\circ} \mathrm{C}$, the time required for radioactive protein to reach the tectum in our fish, with optic nerves of $6.2 \mathrm{~mm}$ average length, indicates a transport rate of $50 \mathrm{~mm} /$ day. However this estimate does not take into account the time required for incorporation of radioactive proline into retinal protein and possible other steps prior to entry of labeled protein into the axon. To clarify this point, we have examined the specific activity of protein in the optic nerve at earlier times and found that there is a 1.5-2 hr delay between injection and appearance of radioactive protein in the nerve (Elam and Agranoff, 1971). Thus the rate of transport in the nerve per se is on the order of $70-100 \mathrm{~mm} /$ day.

When fish are stored at reduced temperatures, the time required for radioactive protein to reach the tectum is increased (Figs. 4 and 5). Some of this delay may be due to a slowing of metabolic events in the eye

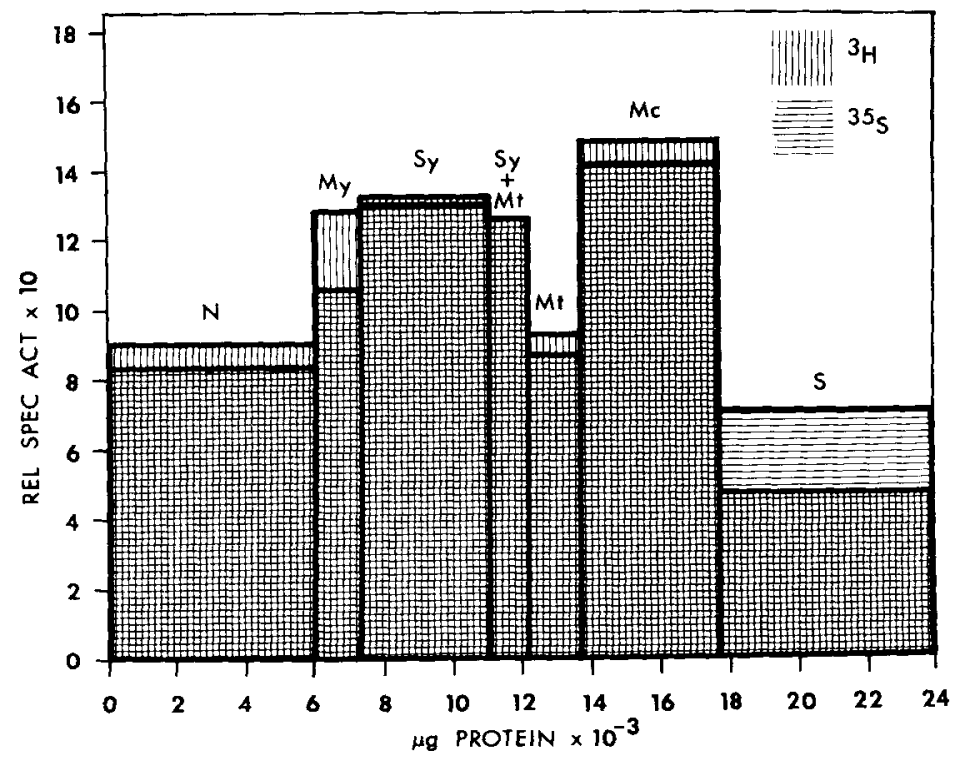

Fig. 7. Labeling of subcellular fractions of left tecta following injection of ${ }^{3} \mathrm{H}$ proline $(1.5 \mu \mathrm{Ci})$ and ${ }^{35} \mathrm{SO}_{4}(15 \mu \mathrm{Ci})$. Fractionation methods (Elam and Agranoff, 1971) were those described previously, with the exception that the discontinuous gradient was centrifuged for $60 \mathrm{~min}$ rather than $120 \mathrm{~min}$. ${ }^{3} \mathrm{H}$ radioactivity was measured in protein, ${ }^{35} \mathrm{~S}$ radioactivity was measured in chloroform: $\mathrm{MeOH}-\mathrm{MeOH}: \mathrm{H}_{2} \mathrm{O}$ residue. iThe ordinate represents the specific activity of the fraction relative to the specific activity of the homogenate. The abscissa gives the cumulative amount of protein in the fractions; (N) crude nuclear; (My) myelin; (Sy) synaptosomes; (Mt) mitochondria; (Mc) microsomes; (S) soluble. 
prior to entry of protein into the axon, rather than a reduction in the rate of transport per se. Further experiments have been conducted in which fish were maintained at $18^{\circ} \mathrm{C}$ for $1.75 \mathrm{hr}$ after injection, a time at which the incorporation process is complete, then transferred to $11^{\circ} \mathrm{C}$ water for the remainder of the experiment. As seen in Figure 6, there is still a substantially reduced rate of accumulation of transported protein in the tectum despite the "normal" period of synthesis in the eye. This suggests that the transport rate is in fact reduced at lower temperatures and also that there is no obligatory coupling between the rate of synthesis of transported protein and its subsequent rate of transport.

When fish are maintained at $10^{\circ} \mathrm{C}$ for 2 weeks prior to injection, the apparent reduction in transport rate is still observed (Elam and Agranoff, 1971). It would appear that there is no long-term metabolic acclimation and that fish stored at lower temperatures are able to function for prolonged periods with reduced transport rates.

Subcellular studies. We have previously reported that rapidly transported protein labeled with ${ }^{3} \mathrm{H}$-proline is highly particulate and is recovered in a variety of subcellular fractions including synaptosomes, myelin, free mitochondria and microsomes (Elam and Agranoff, 1971). Purified nuclei and ribosomes appear to be relatively devoid of radioactivity. Results of a fractionation of tecta doubly labeled with ${ }^{3} \mathrm{H}$-proline and ${ }^{35} \mathrm{SO}_{4}$ are seen in Figure 7 . With the exception of the soluble fraction, the distribution of the two isotopes is remarkably similar. As has been shown previously for ${ }^{3} \mathrm{H}$-proline (Elam et al., 1971), the particulate ${ }^{35} \mathrm{~S}$ is not readily solubilized by mild treatment with Triton X-100, urea or salt. The bound radioactivity is thus most likely not an artifact of the isolation procedure. Since rapidly transported protein appears to remain largely presynaptic (Grafstein, 1967; Hendrickson, 1969), radioactivity recovered in nonsynaptosomal fractions is presumably derived from damaged synaptosomes and terminal portions of the optic nerve fibers.

Both ${ }^{35} \mathrm{~S}$ and ${ }^{3} \mathrm{H}$ specific radioactivity is undiminished in myelin which has been purified by hypotonic washes and reisolated on a discontinuous gradient. Although it is unlikely that any of the major myelin proteins would be of neuronal origin, the data indicate that there are neuronal proteins which are difficult to remove from myelin preparation and which may be associated with myelin in situ.

We have interpreted the labeling of the free mitochondrial fraction as suggestive of rapid transport of mitochondria or of mitochondrial proteins and their subsequent release from ruptured synaptosomes during isolation (Elam and Agranoff, 1971). However, since electron microscopic studies have indicated some contamination of this fraction by synaptosomes (Elam et al., 1971), the possiblity arises that synapotosomes of high specific activity contribute to the radioactivity of the mitochondrial fraction.

The microsomal fraction consistantly shows the highest specific radioactivity. This may be related to the fact that this fraction contains large 


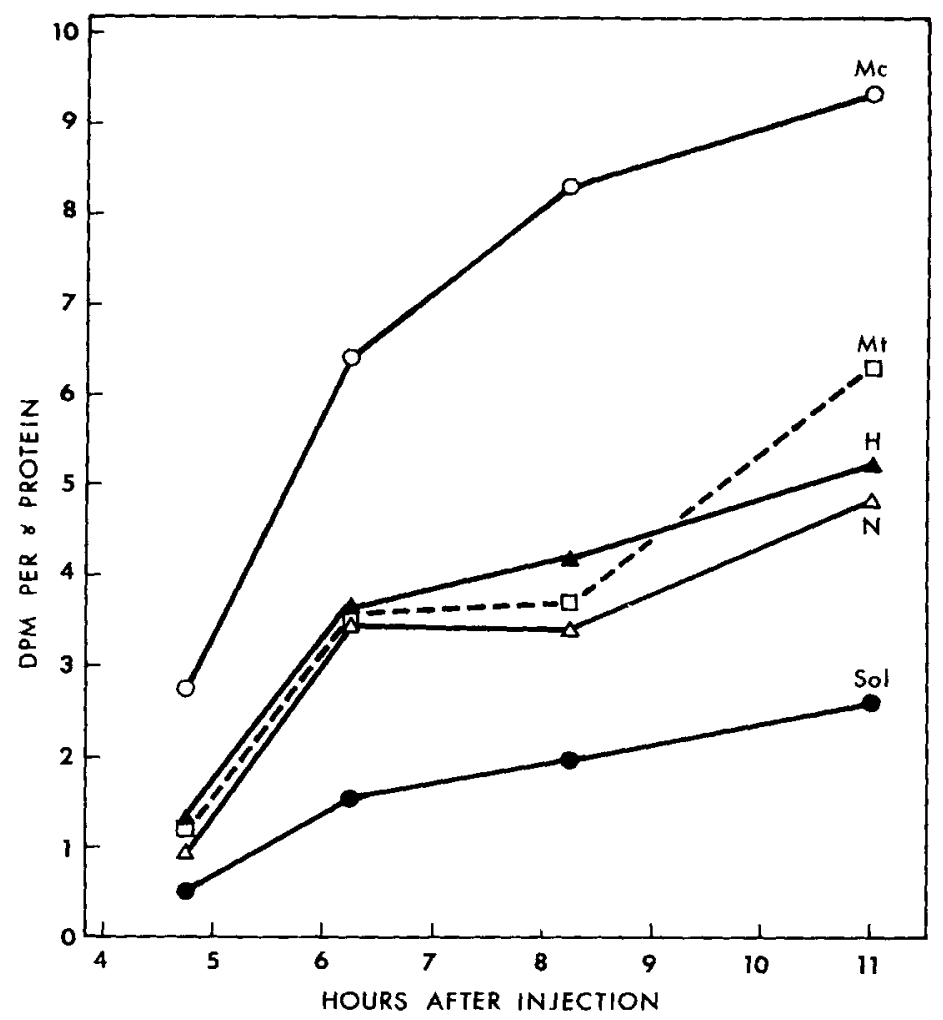

Fig. 8. Labeling of subcellular fractions during the arrival of rapidly transported protein. Fish were injected with $2.5 \mu \mathrm{Ci}{ }^{3} \mathrm{H}$-proline at $17^{\circ}$. At various times groups of 10 were sacrificed and left tecta were homogenized $(H)$ and subfractionated into nuclear (N), crude mitochondrial (Mt), microsomal (Mc), and soluble (S) fractions as described previously (Elam and Agranoff, 1971).

numbers of damaged synaptosomes (Elam et al., 1971). We have found that synaptosomal fractions reisolated after hypo-osmotic shock have up to two-fold higher specific activities that the corresponding untreated fractions (Elam and Agranoff, unpublished results).

The data shown in Figure 8 indicate that the labeling pattern for the basic subcellular fractions does not change appreciably during the various stages of arrival of rapidly transported protein. It appears that there is no extensive shift of labeled material from one fraction to another within this period.

Turnover studies. An advantage of studying rapidly transported proteins in nerve terminals is the possibility of measuring subsequent turnover of these molecules. Figure 9 shows the time course obtained from a double label ${ }^{3} \mathrm{H}$-proline- ${ }^{35} \mathrm{SO}_{4}$ experiment examining the $6-16 \mathrm{hr}$ post-injection period. It appears that the ${ }^{25} \mathrm{~S}$ radioactivity reaches a peak value at $8-10 \mathrm{hrs}$, then begins to decline. In contrast, the ${ }^{3} \mathrm{H}$ radioactivity shows a constant or slightly increasing value during this 


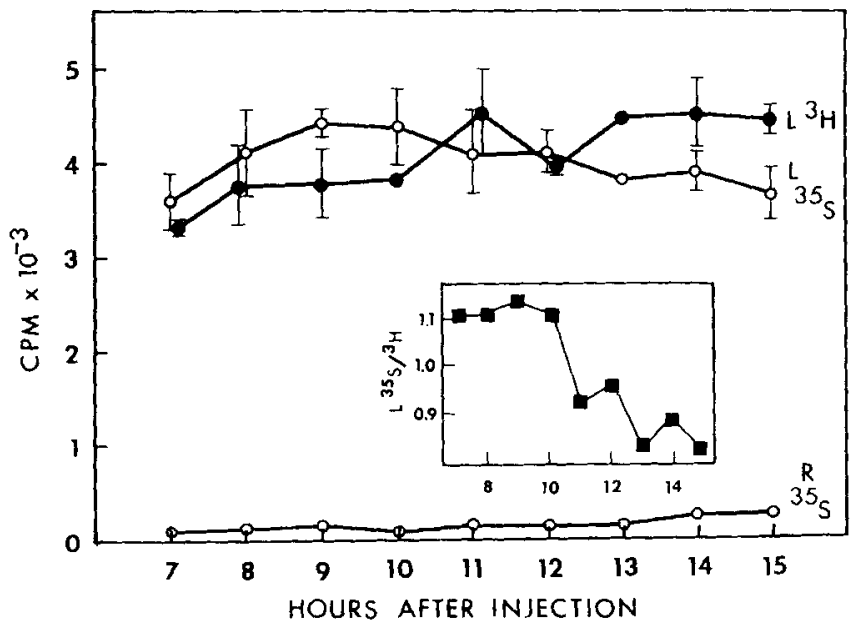

Fig. 9. Radioactivity in tectal protein $\left({ }^{3} \mathrm{H}\right)$ and chloroform: $\mathrm{MeOH}-\mathrm{MeOH}: \mathrm{H}_{2} \mathrm{O}$ residue $\left.{ }^{35} \mathrm{~S}\right)$ after intraocular injection of ${ }^{3} \mathrm{H}$-proline $(0.9 \mu \mathrm{Ci})$ and $\mathrm{Na}_{2}{ }^{35} \mathrm{SO}_{4}(15 \mu \mathrm{Ci})$. Two sets of 4 fish were analyzed at each time point. The average of the two sets is plotted; flags represent the range.

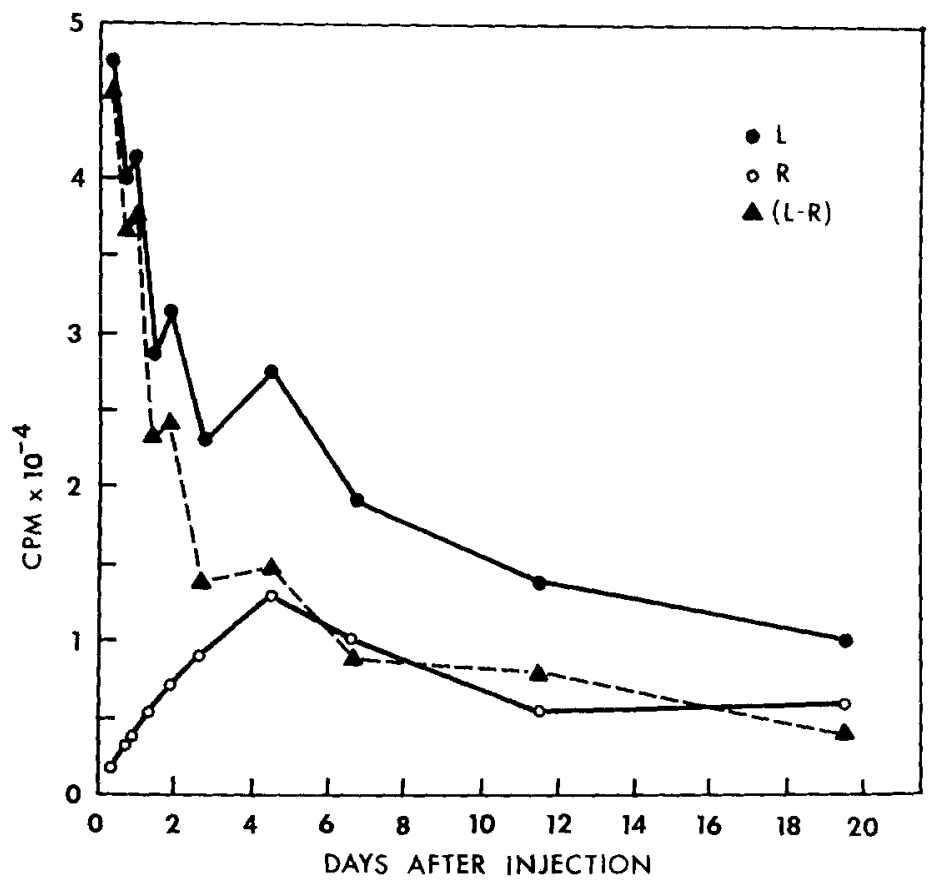

Fig. 10. Radioactivity in chloroform:methanol-methanol: $\mathrm{H}_{2} \mathrm{O}$ residue of left and right tecta after intraocular injection of $30 \mu \mathrm{Ci}$ of $\mathrm{Na}_{2}{ }^{35} \mathrm{SO}_{4}$. Tecta from 10 fish were analyzed at each time point. 


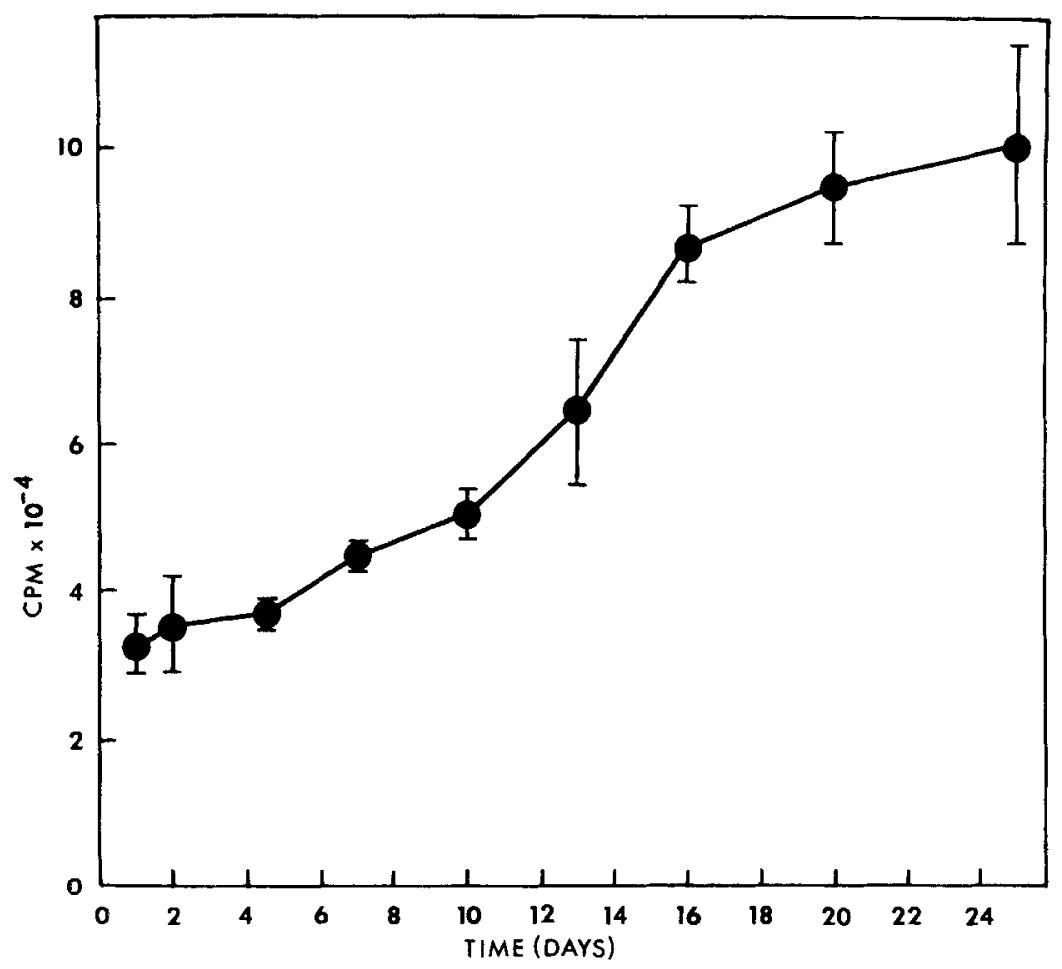

Fig. 11. Long term labeling of left tectal protein following intraocular injection of $5 \mu \mathrm{Ci}$ of ${ }^{3} \mathrm{H}$-proline. Two groups of 5 fish were analyzed at each time point. The average of the two values is plotted; flags represent the individual values.

period. The pattern obtained at later times extending to 25 days is seen in Figure 10 for ${ }^{35} \mathrm{~S}$ and in Figure 11 for ${ }^{3} \mathrm{H}$. The ${ }^{35} \mathrm{~S}$ shows a biphasic turnover in the tectum with roughly equal amounts having half-lives of 1 day and 7 days respectively. There is no indication of a peak of radioactivity associated with slowly transported protein. Both the mucopolysaccharides and the cetylpyridinium bromide non-precipitable fractions show the biphasic kinetics. It should be noted that right tectal ${ }^{35} \mathrm{~S}$ radioactivity becomes significant after the first $10 \mathrm{hrs}$ and must be subtracted.

The ${ }^{3} \mathrm{H}$ radioactivity in the left tectum remains relatively constant for about 4 days then increases as more slowly transported protein begins to reach the tectum (Fig. 11). The ${ }^{3} \mathrm{H}$ radioactivity reaches a peak at about 30 days and appears to turn over with a half-life in excess of 100 days (Grafstein, 1967; Elam and Agranoff, unpublished).

The rapid turnover of the ${ }^{35} \mathrm{SO}_{4}$ is intriguing in view of its implication that these residues are subject to immediate utilization in synaptosomal functioning. The disparity in the rate of turnover of ${ }^{35} \mathrm{~S}$ and ${ }^{3} \mathrm{H}$ is not in itself paradoxical. It is possible that sulfate is turning over independently of the protein portion of the sulfated glycoprotein molecules. Also the 
fraction of the transported proteins binding sulfated carbohydrates may be small and therefore would difficult to detect if it were undergoing rapid turnover.

The ${ }^{3} \mathrm{H}$ of both rapidly and slowly transported proteins appears to be turning over relatively slowly. It is possible, however, that a somewhat more dynamic situation occurs. Release of ${ }^{3} \mathrm{H}$ from the rapidly transported protein could be masked by a continued arrival of progressively more slowly migrating species from the highly labeled retina. The general pattern of slow turnover of the transported proteins more likely indicates that the majority of these materials are not immediately consumed in synapto somal activity but are perhaps incorporated into more stable membranous and structural elements of the synapse.

\section{REFERENCES}

Bondy, S. and Morkilos, B. (1971). Axoplasmic flow of nucleic acids and glycoproteins. Trans. Am. Soc. Neurochem. 2: 58.

Carton, H. and APPEL, S. (1971). Differential labeling of synaptic membrane proteins by local synthesis and fast axoplasmic flow. Trans. Am. Soc. Neurochem. 2: 60 .

Cú́nod, M. and Schonbach, J. (1971). Synaptic proteins and axonal flow in the pigeon visual pathway. J. Neurochem. 18: 809-816.

Elam, J. S. and Agranoff, B. W. (1971). Rapid transport of protein in the optic system of the goldfish. J. Neurochem. 18: $375-387$.

Elam, J. S., Goldberg, J. M., Radin, N. S. and Agranoff, B. W. (1970). Rapid axonal transport of sulfated mucopolysaccharide proteins. Science 170: 458-460.

Elam, J. S., Neale, E. A. and Agranoff, B. W. (1971). Axonal transport in the goldfish visual system. Acta Neuropath. in press.

Forman, D. S., McEwen, B. S. and Grafstein, B. (1971). Rapid transport of radioactivity in goldfish optic nerve following injections of labeled glucosamine. Brain Res. 28: $119-130$.

Grafstein, B. (1967). Transport of protein by goldfish optic nerve fibers. Science 157: $196-198$.

Grafstein, B. (1969). Axonal transport: Communication between soma and synapse. In: Advances in Biochemical Psychopharmacology (E. Costa and P. Greengard, Eds.) Raven Press, New York, Vol. 1, pp. 11-25.

Hendrickson, A. (1969). Electron microscopic radioautography: Identification of origin of synaptic terminals in normal nervous tissue. Science 165: 194-196.

Marchisio, P. C. and Suöstrand, J. (1971). Axonal transport in the avian optic pathway during development. Brain Res. 26: 204-211.

Margolis, R. K. and Margolis, R. V. (1970). Sulfated glycopeptides from rat brain glycoproteins. Biochem. 9: 4389-4396.

McEwen, B. S. and Grafstein, B. (1968). Fast and slow components in axonal transport of protein. J. Cell Biol. 38: 494-508.

WEIss, P. (1969). Neuronal dynamics and neuroplasmic (axonal) flow. Symp. Int. Soc. Cell. Biol. 8: 3 -34. 